ЕМПІРИЧНЕ ПРАВОЗНАВСТВО

УДК 340.132 .6

DOI: https://doi.org/10.32631/pb.2019.3.09

ВАЛЕРІЯ КОСТЯНТИНІВНА АНТОШКІНА,

кандидат юридичних наук, доцент,

Бердянський університет менеджменту і бізнесу,

кафедра галузевих юридичних дисциплін;

https://orcid.org/0000-0003-2136-3073,

e-mail:fair_isle@rambler.ru

\title{
ОЗНАКИ ТА ОСОБЛИВОСТІ ПРАВА, ЯКІ ОБУМОВЛЮЮТЬ НЕОБХІДНІСТЬ ТЛУМАЧЕННЯ
}

\begin{abstract}
Цю статтю присвячено розгляду питання впливу визначальних рис і особливостей права на процес тлумачення. Автор наводить думки вчених-правознавців щодо причин, які обумовлюють необхідність тлумачення правових приписів. Погоджуючись із наведеними твердженнями та висновками, він аналізує вказані підстави більш докладно, розділивши на об'єктивні (не можна усунути і не можна трактувати як провина законодавця) і суб'єктивні (результат упущень суб'єктів правотворчості), та доповнює їх.

Також у статті звернуто увагу на те, що при здійсненні тлумачення інтерпретатор права має враховувати особливості режиму правового регулювання, основні засади, принципи і підходи до викладення норм тієї чи іншої галузі права та ін.
\end{abstract}

Ключові слова: особливості тлумачення, об'єктивні причини тлумачення, суб'єктивні причини тлумачення, оцінні поняття у праві, галузеві особливості тлумачення.

Оригінальна стаття

\section{Постановка проблеми}

Ефективність правового регулювання значною мірою залежить від чіткості та зрозумілості правових приписів, їхньої системності та взаємної узгодженості. Проте законотворчий процес завжди пов'язаний із фрагментарністю зміни нормативних положень та існуванням часових проміжків у реалізації законотворчої ініціативи. Все це спричиняє нечіткість нормативних приписів та відповідну необхідність їхнього подальшого тлумачення правозастосовчими органами і теоретиками права. Дослідження та розуміння причин, які обумовлюють необхідність тлумачення з урахуванням особливостей різних галузей права, дозволить удосконалити не тільки правоінтерпретаційний, а й нормотворчий, правозастосовний процеси.

\section{Стан дослідження проблеми}

Проблеми тлумачення правових норм висвітлювались у працях таких вітчизняних і зарубіжних науковців, як: С. С. Алексєєв, У. Бернам, Є. В. Васьковський, О. Б. Венгеров, М. О. Власенко, Ю. Л. Власов, М. М. Вопленко, О. В. Капліна, П. О. Недбайло, А. С. Піголкін, П. М. Рабінович, Б. П. Спасов, А. О. Селіванов, І. Д. Сліденко, В. Я. Тацій, Ю. М. Тодика, Г. О. Христова, О. Ф. Чер- данцев, Ю. С. Шемшученко та ін. Проте питання про підстави, які викликають необхідність тлумачення, потребує детальнішого вивчення.

\section{Мета і завдання дослідження}

У загальній теорії права розроблено базові підходи щодо тлумачення норм, але вони потребують більш пильної уваги та вдосконалення, особливо на сучасному етапі розвитку нашого суспільства в умовах постійного оновлення нормативного матеріалу. Саме тому метою статті $є$ дослідження підстав тлумачення, в тому числі з урахуванням особливостей різних галузей права та законодавства. Вважаємо, що ця мета може бути досягнутою шляхом вирішення певних завдань:

1) аналізу наведених в науковій літературі положень щодо причин, які обумовлюють необхідність тлумачення у праві.

2) систематизації підстав тлумачення у праві та визначення особливостей різних галузей права і законодавства, що $є$ визначальними для процесу тлумачення.

\section{Наукова новизна дослідження}

Чітке розуміння причин, які обумовлюють необхідність тлумачення у праві, дозволяє 
удосконалювати техніку юридичного тлумачення, розширювати його інструментарій, обирати спосіб і прийом тлумачення, що найбільш доцільні для тлумачення того чи іншого об'єкта інтерпретації.

\section{Виклад основного матеріалу}

В науковій літературі висловлювалися різні думки щодо причин, які обумовлюють необхідність тлумачення правових приписів. Зокрема, Л. Н. Александрова так пояснює це явище: 1) норми права, що містяться в нормативних актах, виражаються за допомогою слів, пропозицій, формулювань, для розуміння сенсу яких, значення і логічного зв'язку між ними потрібна розумова діяльність; 2) в нормативних актах воля держави виражена через засоби і прийоми юридичної техніки, що потребує для правильного їх пояснення спеціальних юридичних знань; 3) мова закону не спрямована на конкретну особу, текст закону відзначається безособовістю викладу, стислістю формулювань, а також великою формалізацією, що веде до частого виникнення у правозастосувача необхідності розшифровування цих формулювань; 4) недосконалість і неадекватне використання законодавчої техніки [1, с. 21].

У свойй роботі Г. О. Саміло виокремлює дещо інші ознаки й особливості норм права, які викликають необхідність тлумачення:

1. Норми права мають загальний і абстрактний характер, коло їх дії поширюється на велику кількість суб'єктів і ситуацій, але разом 3 тим вони реалізуються в конкретних діях осіб у конкретних випадках. Отже, виникає потреба наблизити формальне його правило до конкретних дій суб’єкта і ситуацій.

2. Кожна норма права регулює певний вид суспільних відносин, окреслений у ній загальними рисами. Конкретні відносини, які регулює норма права, $є$ вельми численними. Вони мають індивідуальні особливості і водночас суттєві риси, характерні для всіх видів відносин. Ця обставина у процесі реалізації норм права породжує багато питань, що належать до змісту норм права, відповіді на які можна отримати лише шляхом тлумачення.

3. Норми права діють досить тривалий час. У період їх дії в результаті розвитку економічних та суспільних відносин виникають нові ситуації, які підпадають під регулювання певних норм права внаслідок їх загального характеру.

4. Норми права мають певну мовно-логічну зовнішню форму, особливості якої потребують тлумачення.
5. Логічні форми не тотожні граматичним, логіка не зливається з граматикою. Слово не дає повного уявлення про сутність речі, яку воно означає, слова не мають єдиної інтерпретації. Зв'язок між словом і поняттям ускладняються тим, що значення слова у мові охоплює не весь зміст поняття, а лише загальновідому його частину, і тут слово опиняється у своєму значенні вужчим за поняття.

6. Суб’єкти суспільних відносин належать до різних соціальних верств, професій, мають різний життєвий досвід, різну правову і моральну свідомість, сприймають однакові явища дійсності з різним ступенем точності, широти і глибини [2, с. 11-13].

Із вищенаведеними думками та висновками можна повністю погодитися, однак вважаємо за доцільне розглянути вказані підстави більш докладно та доповнити їх.

Отже, можемо таким чином окреслити ті явища правової дійсності, що є визначальними для процесу тлумачення у праві та мають бути враховані особами, які здійснюють правоінтерпретаційну діяльність.

1. Однією з основних причин, що спричиняє необхідність тлумачення у сфері права, $€$ загальний характер правових норм. Будь-яка норма права $є$ загальним правилом поведінки у певній сфері соціальних відносин. Установлюючи таке загальне правило, «видавець норми» не може передбачити усі нюанси відносин, що виникають під час іï застосування. Тобто йдеться про неповне охоплення юридичними нормами фактичних умов життя. Тому нерідко для того, щоб норма права почала реально діяти в регулюванні конкретних відносин, потрібно здійснити їі тлумачення, яке б наближало загальне правило до конкретного випадку.

Наприклад, під час застосування законодавчих норм про спадковий договір у практиці постало питання щодо форми та виду дій, які набувач за договором має здійснити до або після відкриття спадщини. У процесі вирішення конкретних справ суди визначають, чи можна визначити здійснені набувачем дії такими, що відповідають вимогам закону.

Певною мірою необхідність і особливості тлумачення правових норм обумовлені правовими властивостями самих галузей права, які відображають природу регульованих ними відносин. Ці особливості і властивості відіграють важливу роль у процесі правильного розуміння і застосування норм відповідного законодавства. Значна різниця у підходах залежить від того, приватна чи публічна галузь права. Одним із таких важливих чинників $€$ 
тип правового регулювання, тобто спосіб сполучення (поєднання) юридичних дозволів і заборон, на котрих базується регулювання: загальнодозвільний (грунтується на загальному дозволі) і спеціально-дозвільний (грунтується на загальній забороні) [3, с. 138]. Окрім цього, треба враховувати основні засади кожної галузі права, які або закріплені у відповідному законодавстві, або визначені в науковій літературі на підставі аналізу нормативного матеріалу.

Також, якщо йдеться про цивільне, сімейне чи господарське право, тут $\epsilon$ широта сфери їх дії - від відносин фізичних осіб майнового та немайнового характеру до відносин на промисловому ринку. Це призводить до обширності і складності законодавства та, відповідно, до необхідності тлумачення під час реалізації норм.

3. Для написання текстів нормативноправових актів законодавцем нерідко здійснюється свідоме використання термінів, які не мають єдиного значення. Такі поняття можуть мати подвійне, а інколи - невизначене коло значень. У сучасних нормативно-правових актах часто можна побачити застосування такого правового прийому: у першій статті того чи іншого нормативного акта вказується, що певний термін має відповідне значення "для цілей цього закону». Вказане свідчить про те, що законодавець розуміє обмеженість установленого ним визначення і розглядає його виключно для певної правової мети - регулювання указаного виду відносин. Цим він допускає, що в інших відносинах вказаний термін може набувати іншого значення. Зокрема, у статті 14 Податкового кодексу України № 2755-VI від 02.12.2010 дається роз'яснення термінів, які використовуються в зазначеному нормативно-правовому акті.

Різне значення семантично однакових термінів інколи спричиняє на практиці багато проблем. В окремих випадках воно тягне за собою необхідність втручання вищих судових органів та здійснення офіційного тлумачення. Зокрема, внаслідок виникнення конкретних проблем під час тлумачення терміна «член сім'ї» Конституційний Суд України 3.06.1999 вимушений був надати його офіційне тлумачення. При цьому він зазначив, що стосовно поняття «член сім'ї» Конституційний Суд України виходить з об'єктивної відмінності його змісту залежно від галузі законодавства ${ }^{1}$. От-

1 Рішення Конституційного Суду України у справі за конституційними поданнями Служби безпеки України, Державного комітету нафтової, же, поняття «член сім'ї», що використовується в податковому, житловому, цивільному, сімейному законодавстві, може мати різне значення, залежно від мети правового регулювання вказаних видів відносин.

Укладання волі законодавця в нормативний правовий акт відбувається за допомогою прийомів юридичної техніки з використанням спеціальної юридичної термінології, юридичних конструкцій і відсилань. Має місце свідоме використання в законодавстві термінів, які не мають єдиного значення. Усе це говорить про необхідність володіння спеціальними знаннями в цій галузі.

4. Необхідність застосування тлумачення має причиною використання в нормативних актах термінів, які не визначені в законодавстві та мають оціночний характер. Такий прийом юридичної техніки, як включення в текст правових норм оцінних понять, забезпечує гнучкість правового регулювання, дає можливість під час застосування норм врахувати зміни в суспільному житті, що відбуваються в явищах, описаних з їх допомогою. Разом з тим здійснення відповідного тлумачення нормативних положень 3 оцінними поняттями дуже часто вимагає особливих професійних знань і умінь. У цьому випадку підстави для тлумачення мають об'єктивний характер. Зокрема, суди у процесі розгляду конкретних спорів визначають такі поняття як «істотне порушення договору», «намір завдати шкоду іншій особі», «справедливий розподіл витрат між сторонами», «нормально необхідний час для відповіді» «істотна шкода», «необхідна і достатня шкода», «тяжка шкода», «тяжкі наслідки», «достатні підстави», «явно злочинний наказ або розпорядження», «належні для високопродуктивної роботи умови праці», «вчинок державного службовця, який порочить його як державного службовця або дискредитує державний орган, у якому він працює», «неповна службова відповідність», «ділові якості особи», «виняткові випадки» тощо. Це приклади оцінних понять 3 різних галузей права - цивільного, кримінального, адміністративного.

газової та нафтопереробної промисловості України, Міністерства фінансів України щодо офіційного тлумачення положень пункту 6 статті 12 Закону України «Про соціальний і правовий захист військовослужбовців та членів їх сімей», частини четвертої і п'ятої статті 22 Закону України «Про міліцію» та частини шостої статті 22 Закону України «Про пожежну безпеку» (справа про офіційне тлумачення терміна «член сім'ї») : від 03.06.1999 № 5-рп/99. 
У цьому зв'язку можна дійти закономірного висновку, що оскільки законодавчо неможливо закріпити зміст оціночної норми права, у процесі правозастосування такої норми, існує реальна необхідність виявляти зміст конкретного оцінного поняття шляхом його системного тлумачення і конкретизації.

5. Тлумачення нормативних приписів може пов'язуватися також 3 нечіткістю та суперечливістю існуючих нормативних положень. Такі випадки непоодинокі. Їх можна пояснити не об'єктивними, а суб'єктивними факторами - недостатньою «якістю» нормативного матеріалу, упущеннями, які виникають у процесі прийняття законів, відсутністю наукової експертизи проєктів нормативних актів тощо. Непоодинокими $є$ випадки, коли норми, що містяться навіть в одному нормативному акті, прямо не співпадають між собою. Такий незбіг правових приписів обов'язково потребує тлумачення, оскільки не може вирішуватися однозначно.

На жаль, ця підстава тлумачення $є$ вкрай актуальною для вітчизняної системи законодавства, матеріал щодо цього питання значний за обсягом і потребує окремого розгляду в подальшому.

6. Варто зазначити, що складність тлумачення не в останню чергу викликана значним обсягом нормативного матеріалу, а також тим, що об'єктом тлумачення можуть виступати не лише закони і підзаконні акти нашої держави, а й міжнародні договори та звичаї. Адже згідно з положеннями ст. 9 Конституції України «чинні міжнародні договори, згода на обов'язковість яких надана Верховною Радою України, $\epsilon$ частиною національного законодавства України».

7. У рамках цього дослідження доцільним $\epsilon$ визначення такої специфічної проблеми тлумачення, як дуалізм приватного права, оскільки маємо два нормативні акти - Господарський кодекс України та Цивільний кодекс України. Причому перший не просто не доповнює останній, а й установлює окреме від Цивільного кодексу правове регулювання таких базових інститутів приватного права, як суб'єкти, речове та договірне право тощо, що не може сприяти адекватному тлумаченню норм.

Зокрема, відсутність у цивілістиці поняття корпоративних прав як майнових та немайнових прав учасників товариства вимагає вироблення відповідної доктрини для оперування ними як об'єктами цивільних прав під час вирішення спорів. Ці положення містяться у господарському законодавстві, що приводить до думки, що вони не є цивільно-право- вими і не входять до сфери цивільно-правових відносин. Проте на практиці мають місце численні випадки продажу корпоративних прав приватними особами. У цьому аспекті проблематику питання вірно визначає I. В. Спасибо-Фатєєва: «як співвідносяться між собою ці права та права учасника господарського товариства (ст. 116 ЦК та ін.), право на частку учасника господарського товариства в статутному (або складеному) капіталі (ст. 143, 147 ЦК та ін.), право участі в товаристві (ст. 100 ЦК), майнове право (ст. 177 ЦК) [4, с. 16].

Правильною нам видається позиція І. Л. Євміної, що «дуалізм права не можна підміняти дуалізмом приватного (цивільного) права, де господарське законодавство пропонують розглядати як просте відгалуження від цивільного (пандектного) права і зводити пріоритет до простого пріоритету спеціальної норми щодо загальної» [5, с. 74].

За позицією ВГСУ, викладеною в Інформаційному листі від 7 квітня 2008 р. № 01-8/211, ЦК України та ГК України співвідносяться як загальний та спеціальний закони - під час правозастосування застосовується закон не в цілому, як нормативно-правовий акт, а відповідна правова норма чи її частина, за змістом якої і визначається, чи $\epsilon$ ця норма (ії частина) спеціальною чи загальною. Тому в разі, якщо норми ГК України не містять спеціальних норм, а встановлюють загальні правила, які не узгоджуються з відповідними правилами ЦК України, слід застосовувати правила, встановлені ЦК України.

Так, норми ГК України про недійсність господарських зобов'язань суперечать положенням ЦК України про недійсність правочинів як за термінологією, так і за змістом тому, що не містять особливостей регулювання господарських відносин, а містять загальні правила про недійсність господарських зобов'язань. Тому ст. 207 ГК України відповідно до абз. 1 та 2 ч. 2 ст. 4 ЦК України застосовуватись не може.

Крім того, право $є$ складною взаємозв'язаною системою, в якій кожна правова норма не може працювати сама по собі. Наприклад, у процесі усиновлення задіюється і цивільне право, і процесуальне, і норми сімейного права, які призначені для усіх, але в конкретному випадку працюють для однієї приватної особи.

8. Необхідність тлумачення правових норм обумовлюється також особливістю зовнішнього оформлення норм права. У цьому аспекті вірною нам видається думка С. С. Алексєєва, що необхідність тлумачення правового акта витікає з тих самих причин, що обумовлюють 
необхідність тлумачення будь-якої форми мови [6, с. 291-292]. 3'ясування будь-якого тексту вимагає певної розумової діяльності, тобто дій з розпізнавання знакової системи - слів, речень, їх логічного зв'язку.

До цього слід додати, що норми права формуються і фіксуються через слова і їх поєднання, які використовуються законодавцем, проте «логічні форми не тотожні граматичним, логіка не зливається з граматикою» [7, с. 170].

Отже, пояснюється необхідність тлумачення тим, що нормативно-правові акти містять загальні, в деяких випадках абстрактні нормативні положення, викладені не тільки в знаковій системі, мовно-структурному вигляді, але і «юридичною мовою». Все це вимагає напруженої розумової діяльності, із суб'єктивним і об'єктивним використанням юридичних та інших спеціальних знань.

9. Як особлива умова, що впливає на процес тлумачення, - вплив міжнародно-правового регулювання. Міжнародні конвенції, договори значно вплинули на формування і зміну правових норм, практику їх застосування. Слід також зазначити, що значний обсяг відносин фізичних і юридичних осіб різних держав регулюється галуззю міжнародного права.

Так, зокрема, міжнародні правила щодо тлумачення торгових термінів «Інкотермс», видані Міжнародною торговою палатою, містять у собі інтерпретації різних юридичних положень, що використовуються учасниками міжнародної торгівлі. Вони $є$ приватною неофіційною кодифікацією міжнародних торгових звичаїв. Уперше опубліковані в 1936 році як збірка тлумачень торгових звичаїв, що найчастіше зустрічаються.

Ці терміни складалися в міжнародній практиці протягом тривалого часу і нарешті отримали статус звичаїв у міжнародної торгівлі. Проте у законодавстві різних країн, а іноді й у портах однієї країни, мали місце суттєві розходження щодо змісту торгових термінів. Тому для уніфікації зовнішньоторговельного обігу розробили Інкотермс, що дало змогу закріпити однакові правила тлумачення термінів, найчастіше вживаних у зовнішній торгівлі.

За своїм правовим статусом Інкотермс не $є$ джерелом права за об'єктивним сенсом і не виступають як норми права. Вони отримують юридично обов'язкове значення, якщо сторони в договорі роблять щодо них expressis verbis посилання. Така договірна умова матиме зобов'язуючий характер для контрагентів. У цьому випадку Інкотермс виступають як джерело права в суб'єктивному сенсі (суб'єктивні права і обов'язки сторін договору).
10. Об'єктами тлумачення можуть виступати не тільки нормативно-правові акти, а й правочини. Необхідність у тлумаченні договору виникає в разі неповного або недостатньо ясного формулювання його окремих умов, спростування сторонами або третіми особами його укладення або дійсності, а також його правової природи.

Вирази та слова осіб при укладенні правочинів не завжди однозначно відображають їхню волю. Нерідко під час їх реалізації виникають суперечки відносно змісту окремих положень або умов. Отже, недостатня визначеність умов правочинів, спростування їх наявності, незрозумілість змісту використовуваних понять, необхідність визначення правової природи викликають необхідність тлумачення.

11. Системність правових норм обумовлює послідовність у тлумаченні - тлумачення однієї норми веде до необхідності визначення пов'язаної з нею норми, тому що істинний сенс тлумаченого нормативного припису буде зрозумілим тільки після розгляду взаємозв'язаних норм.

12. Необхідність тлумачення норм права іноді випливає зі змісту самого нормативного акта, коли в ньому зустрічаються вирази «і т. д»., «і т. п»., «інші» тощо. Установити їх істинне значення можливо тільки за допомогою тлумачення

У цілому причини виникнення необхідності в застосуванні тлумачення можна поділити на дві групи:

- об'єктивні - не можна усунути і не можна трактувати як провина законодавця (з'ясування волі законодавця, яка може мінятися $з$ часом, з'ясування будь-якої форми мови, яка має певну автономність від думки, абстрактний характер норм права, з'ясування спеціальних термінів та ін.);

- суб'єктивні - результат упущень суб’єктів правотворчості, які за належного ставлення могли бути усунені під час створення нормативно-правового акту (погана редакція тексту нормативного акта, відсутність спеціальних знань автора нормативного акта, наявність колізій між нормативними актами, що регулюють одне питання, невміле застосування правил правотворчої техніки та ін.).

Таким чином, тлумачення правової норми $\epsilon$ процесом 3'ясування ії змісту (сенсу) через усунення виявлених в ній неясностей, які виникають через низку обставин, зокрема через стислість формулювань нормативноправового акта, що обумовлено самою його природою, через появу нових суспільних відносин і життєвих фактів, що не знаходять 
точних словесних описів у нормативноправових актах, особливостей режиму правового регулювання та викладення норм тієї чи іншої галузі права та ін. Ці проблеми і вирі- шують за допомогою різних видів тлумачення правових норм, основні підстави застосування яких нами узагальнено на рис. 1.

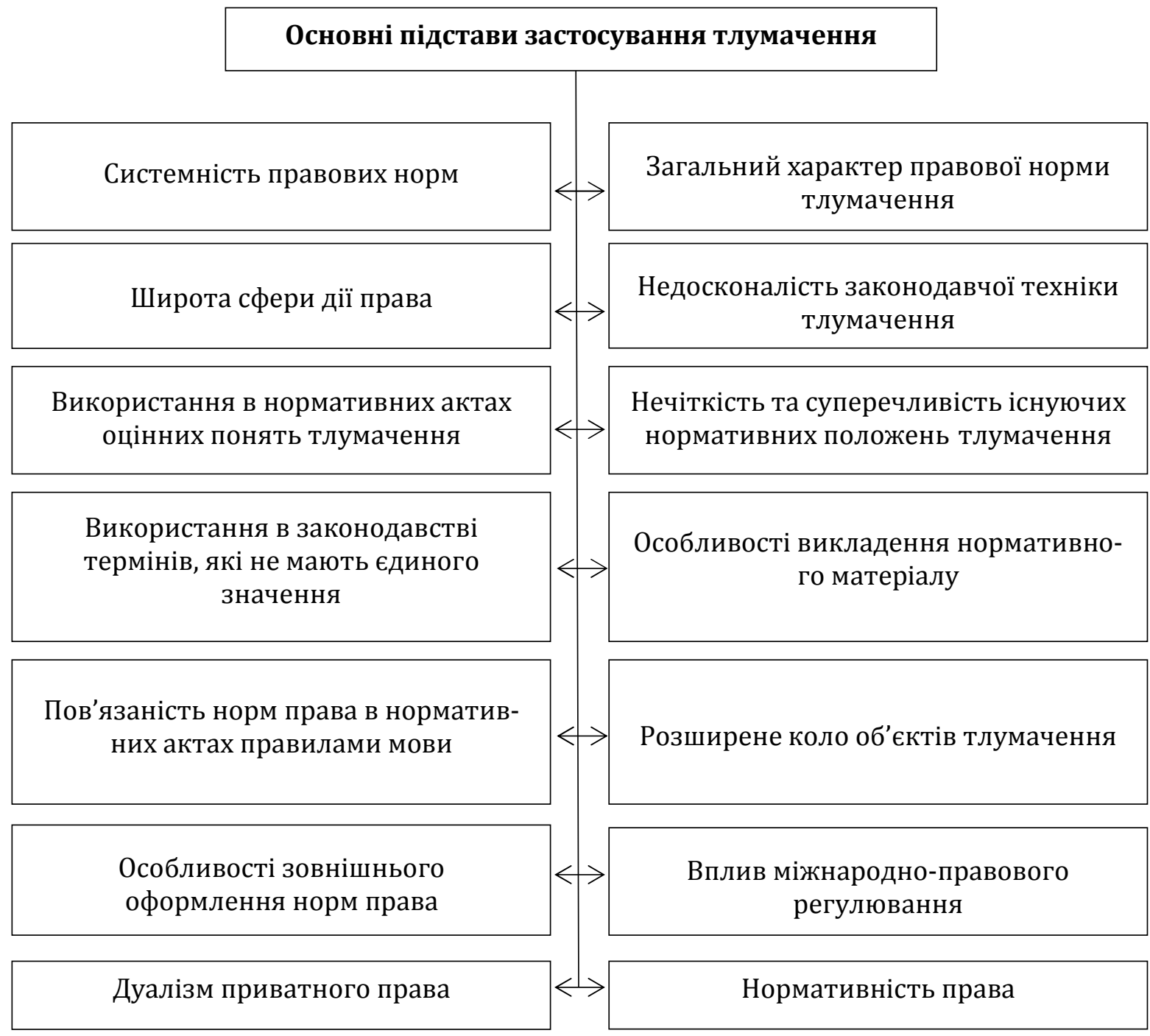

Рис. 1. Основні підстави застосування тлумачення у праві

Як показує проведене дослідження, причини необхідності тлумачення юридичних норм пов'язані не лише з прорахунками, допущеними законодавцем у формулюваннях текстів законів, їх невдалістю, неточністю, нечіткістю і т. п.

\section{Висновки}

Отже, у сфері права широке застосування має процес тлумачення правових норм, існує ціла низка підстав, які спричиняють необхідність здійснення тлумачення правових норм. При цьому слід мати на увазі, особливо законотворцям, що якщо така причина тлумачення, як загальний характер правової норми випливає із самої суті правореалізації, всі інші $є$ знач- ною мірою наслідками недосконалості юридичної техніки і мають поступово усуватися.

Таким чином, судження про необхідність тлумачення права спирається на дуже вагомі аргументи. Причому ця діяльність викликана не лише суб'єктивними, але і об'єктивними причинами. Тому вдосконалення законодавства, усунення правотворчих помилок не спричиняє втрату ролі тлумачення права у процесі його реалізації. Більше того, чим досконаліше чинне законодавство, тим вдумливішим має бути тлумачення його приписів. Адже досконалий закон завжди має дуже високу міру абстрактності закріплених у ньому правил поведінки, що робить актуальними подальші наукові пошуки в даній сфері. 


\section{Список бібліографічних посилань}

1. Александрова Л. Н. Толкование юридических норм и его влияние на судебную практику. Известия Российского государственного педагогического университета им. А. И. Герцена. 2007. № 15 (39). C. 20-24.

2. Саміло Г. О. Проблеми тлумачення правових норм. Запоріжжя : ЗНТУ, 2017. 144 с.

3. Лоскутов Т. О. Щодо типів правового регулювання у кримінальному процесі. Науковий вісник Ужгородського національного університету. Серія «Право». 2015. Вип. 30, т. 2. С. 137-140.

4. Спасибо-Фатєєва I. Правовий аспект інновацій в українських реаліях. Вісник академії правових наук України. 2005. № 1 (40). С. 15-23.

5. Євміна І. Л. Недійсність договорів за цивільним та господарським законодавством: засади правозастосування. Вісник Одеського національного університету. Правознавство. 2014. Т. 19, вип. 2 (23). C. 70-79.

6. Алексеев С. С. Общая теория права : в 2 т. М., 1982. Т. 2. 360 с.

7. Ахматов А. С. Логические формы и их выражение в языке. Мышление и язык. М., 1957. 247 с.

Надійшла до редколегії 19.09.2019

\section{АНТОШКИНА В. К. ПРИЗНАКИ И ОСОБЕННОСТИ ПРАВА, КОТОРЫЕ ОБУСЛАВЛИВАЮТ НЕОБХОДИМОСТЬ ТОЛКОВАНИЯ}

Данная статья посвящена рассмотрению вопроса влияния отличительных черт и особенностей права на процесс толкования. Автор приводит мнения ученых-правоведов о причинах, обуславливающих необходимость толкования правовых предписаний. Соглашаясь с приведенными утверждениями и выводами, он анализирует указанные основания более подробно, разделив на объективные (нельзя устранить и нельзя трактовать как вина законодателя) и субъективные (результат упущений субъектов правотворчества), и дополняет их.

Также в статье обращается внимание, что при осуществлении толкования интерпретатор права должен учитывать особенности режима правового регулирования, основные принципы, принципы и подходы к изложению норм той или иной отрасли права и др.

Ключевые слова: особенности толкования, объективные причины толкования, субъективные причины толкования, оценочные понятия в праве, отраслевые особенности толкования.

\section{ANTOSHKINA V. K. SIGNS AND FEATURES OF LAW CAUSING THE NECESSITY OF INTERPRETATION}

Basic approaches to interpreting norms have been developed in general theory of law, but they require more attention to be paid and their improvement, especially at the current stage of the development of our society in the conditions of constant updating of normative material. That is why the reasons for interpretation, including the specificities of the various spheres of law and legislation, have become the object of the research in this paper.

The author mentions the opinions of legal scholars outlined for the reasons that necessitate the interpretation of legal requirements. Agreeing with the provided statements and conclusions, it is advisable to analyze these reasons more thoroughly and to supplement them.

The author of the paper concludes that the reasons needed for interpretation can be divided into two groups:

- objective - cannot be resolved and cannot be interpreted as the fault of the legislator (clarification of the will of the legislator, which can be changed over time, clarification of any form of language that has some autonomy from thought, abstract nature of the norms of law, clarification of special terms, etc.);

- subjective - the result of faults by legislators, which, in due regard, could have been eliminated while creating a legal act (poor edition of the text of the normative act, lack of special knowledge of the author of the normative act, the presence of conflicts between normative acts, which are regulating the same issue, inappropriate usage of the rules of law-making technique, etc.).

Attention is also paid to the fact that the subject of interpretation of law must take into account the peculiarities of the regime of legal regulation, the main grounds, principles and approaches to the statement of the rules of one or another field of law, etc. These problems are being solved with the help of different types of interpretation of legal norms.

According to the conducted research, the reasons needed to interpret legal norms are connected not only with miscalculations made by the legislator in the formulations of the texts of laws, 
their failure, inaccuracy, discrepancy, etc. Therefore, improving the legislation, eliminating lawmaking errors does not cause the loss of the role of law interpretation in the process of its implementation. Moreover, the better the current legislation is, the more thoughtful the interpretation of its requirements should be. After all, perfect law always has a very high degree of abstractness of the rules of conduct enshrined there, which makes relevant further scientific research in this field.

Key words: features of interpretation, objective reasons for interpretation, subjective reasons for interpretation, evaluative concepts in law, sectoral features of interpretation. 